Abstracta Iranica Abstracta Iranica

Revue bibliographique pour le domaine irano-aryen

Volume 29 | 2008

Comptes rendus des publications de 2006

\title{
L'Iran, la bombe et la démission des nations. Paris, Éditions Autrement, 2006,135 p. (coll. « CERI»)
}

\section{Gilles Riaux}

\section{(2) OpenEdition}

1 Journals

\section{Édition électronique}

URL : http://journals.openedition.org/abstractairanica/32292

DOI : 10.4000/abstractairanica.32292

ISSN : 1961-960X

Éditeur :

CNRS (UMR 7528 Mondes iraniens et indiens), Éditions de l'IFRI

\section{Édition imprimée}

Date de publication : 15 mai 2008

ISSN : 0240-8910

Référence électronique

Gilles Riaux, «L'Iran, la bombe et la démission des nations. Paris, Éditions Autrement, 2006,135 p. (coll. « CERI ») », Abstracta Iranica [En ligne], Volume 29 | 2008, document 365, mis en ligne le 15 septembre 2008, consulté le 26 septembre 2020. URL : http://journals.openedition.org/abstractairanica/32292 ; DOI : https://doi.org/10.4000/abstractairanica.32292

Ce document a été généré automatiquement le 26 septembre 2020.

Tous droits réservés 
L'Iran, la bombe et la démission des nations. Paris, Éditions Autrement, 2006,135 p. (coll. « CERI»)

Gilles Riaux 
1 L'A., reconnu pour ses travaux sur les questions stratégiques, s'intéresse dans cet ouvrage au programme nucléaire iranien, notamment sous l'angle des relations internationales. Le premier chapitre présente le programme nucléaire iranien, en argumentant sur sa seule finalité militaire et non civile. Il doit asseoir la puissance régionale de la République islamique et donner les moyens d'une grande négociation avec les États-Unis. Ensuite, l'A. passe en revue l'ensemble des acteurs internationaux ayant maille à partir avec Téhéran. L'action des pays européens et des États-Unis est critiquée pour son incapacité à placer véritablement Téhéran sous la contrainte. La Russie et la Chine sont jugés comme des partenaires peu fiables pour les Occidentaux. Le Pakistan et l'Inde qui ont respectivement aidé ou vu d'un assez bon œil le programme nucléaire iranien, sont amenés à adopter une position moins conciliante, du fait de leurs liens avec Washington. Suit Israël pour qui le programme nucléaire représente une menace, pouvant remettre en cause l'existence même de l'Etat hébreu. Ensuite, l'A. s'intéresse à des acteurs moins souvent traités, Corée du Nord, Egypte, Arabie Saoudite et Afrique du Sud, consacrant quelques pages à chacun. Le dernier chapitre traite du seul acteur multilatéral, l'IAEA, dont le principal objectif est de contenir les ambitions de Téhéran pour éviter que le dossier nucléaire ne soit transféré au Conseil de Sécurité des Nations Unies. Cette succession de chapitres traitant chacun d'un acteur du jeu politique transforme l'ouvrage en catalogue, ce qui n'aide guère à saisir l'ensemble des dynamiques induites par le programme nucléaire iranien sur le système international. L'A. conclut en soulignant les conséquences stratégiques majeures que fait peser le programme nucléaire iranien sur un Moyen-Orient instable, où plusieurs acteurs entretiennent une forte méfiance réciproque, et les risques d'affaissement qui menacent un des piliers du système international, la nonprolifération.

\section{INDEX}

Thèmes : 13.1. Iran

\section{AUTEURS}

GILLES RIAUX

Paris 